\title{
A Comparative Study on Energy Derived from Biomass
}

\author{
A.M. Algarny, I.M. Al-Naimi and M.A.M Alhefnawy* \\ * College of Architecture and Planning, University of Dammam, Saudi Arabia.
}

Received 7 April 2016; Accepted 17 October 2016

\begin{abstract}
The paper promotes sustainable community through empowering the production and utilization of biomass renewable energy. The aim of this paper is to urge societies to adopt sustainable energy practices and resources; the objective is to appraise the possibilities of biomass energy produced through a neighborhood in Eastern Province, Saudi Arabia. The system incorporates an evaluation of the measure of biomass created, then utilizes two ascertaining techniques to gauge whether the measure of energy can be delivered. The computation strategies are hypothetical, with one drawn from past works and the other from a Biomass Calculation Template performed as part of the Evaluation of Biomass Resources for Municipalities study (EBIMUN) by the Waterford County Council. The outcomes demonstrate that the aggregate potential biogas generation of the study area is around $43,200 \mathrm{~m}^{3}$ /year, the methane mass is around 18,000 $\mathrm{m}^{3}$ /year, and the energy production amount is around $250 \mathrm{MWh}$ /year. Contrasting the capability of biogas creation from both techniques, the figure assessed by EBIMUN is around 7,000 $\mathrm{m}^{3} /$ year less than the hypothetically computed amount. The figures suggest that biogas is worthy of consideration as a renewable source of energy.
\end{abstract}

Keywords: Biomass, Biowaste, Renewable energy, Sustainable energy.

$$
\text { دراسة مقارنة للطاقة المستمدة من الكتلة الحيوية الجارني، إ. م. النعيهي، م. أ. م. الحفناوى* }
$$

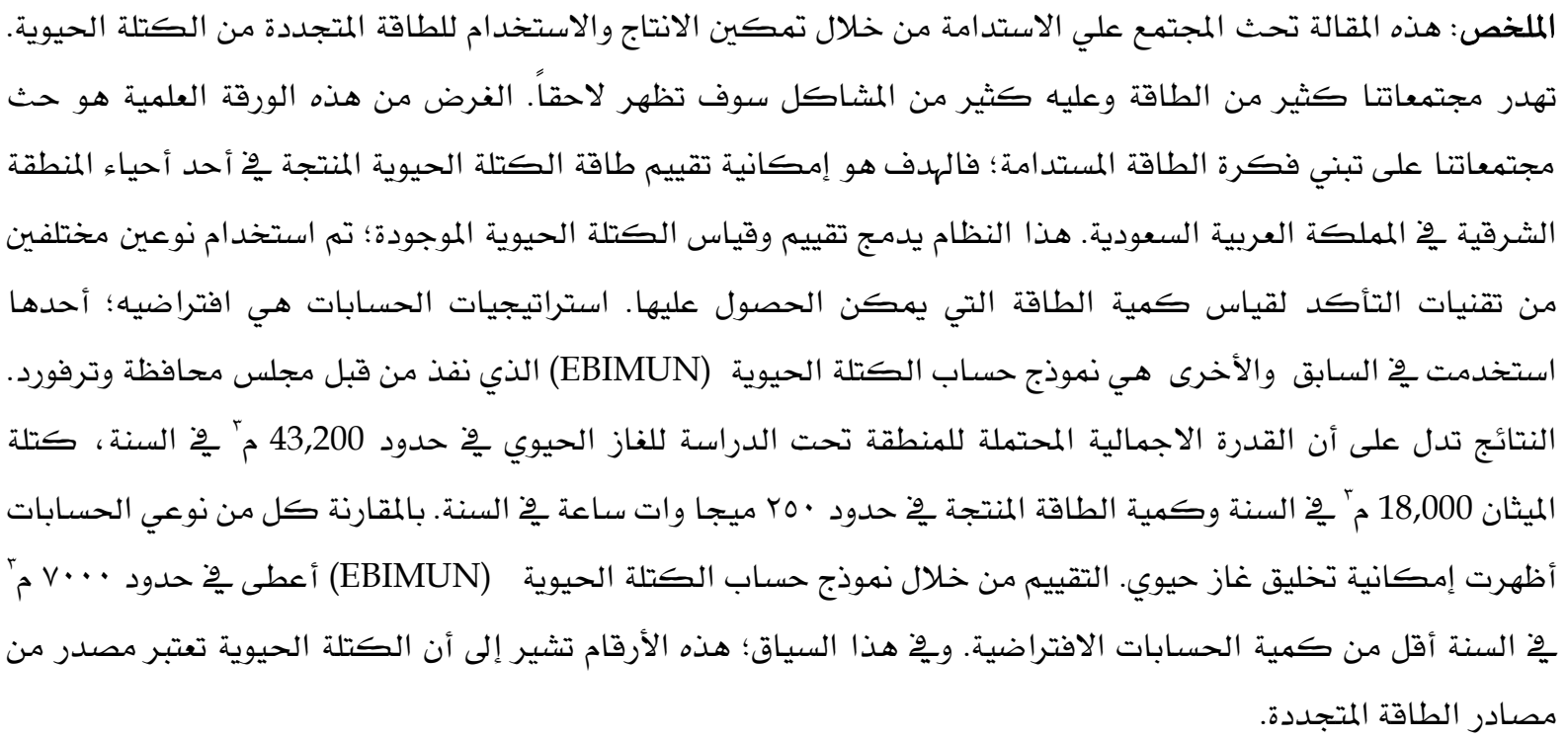

الكلمات المفتاحية: الكتلة الحيوية، النفايات البيولوجية، الطاقة المتجددة، الطاقة المستدامة.

*Corresponding author's email: malhefnawi@uod.edu.sa 


\section{Introduction}

The word biomass denotes the plants and other substances derived from land. It is the oldest and most important source of renewable energy for many reasons. It is renewable, spread around the globe, and is easily collected by environmentally friendly technologies (US Department of Energy 2000). Biomass energies can be derived from a variety of resources, including timber, cultivated lands, agroindustrial wastes, animal waste, sewage, municipal solid waste (MSW), and food handling wastes (Cleantech1 2016).

\section{Waste in the Middle East}

Middle Eastern and North African (MENA) countries have rich unexplored biomass energy resources that hold the potential to generate about 400TWh annually. In the Middle East, 150 million tons of urban waste are generated per year, mainly by Egypt, Yemen, Iraq, Syria, and Jordan. On the other hand, Bahrain, Saudi Arabia, the United Arab Emirates (UAE), Qatar, and Kuwait are among the top ten countries worldwide that produce solid waste per capita (Bioenergy1 2016). Furthermore, Saudi Arabia experiences pollution due to fast development and population growth, and more than 15 million tons of solid waste are annually generated. Solid waste generation has been assessed at 1.5 to $1.8 \mathrm{~kg}$ per capita/day. Having a population of around 29 million, solid waste control is a great challenge for the Kingdom. More than six million tons of solid waste are annually generated in each of the major cities-Riyadh, Jeddah, and Dammam. Recycling, reuse, and energy recovery are getting increased attention, but they are still at an early stage. The recycling rate varies from $10-15 \%$ for metals, paper, and plastics. Composting has received increased attention in Saudi Arabia because of the high organic content of the MSW, which has been observed to reach 40\% (Bioenergy2 2016).

\section{Conversion of Biomass to Energy}

In 2000 , only $1.5 \%$ of the world's electricity was bioenergy-created electricity. On the other hand, the world's biofuel production expanded from 16 billion liters in 2000, to more than 100 billion liters in 2010, constituting 3\% of the world's fuel for transport (Cleantech2 2016).
The yearly prospective biogas generation in Europe has been surveyed at more than 200 billion $\mathrm{m}^{3}$ (Appels et al. 2008). Biomass-based energy constituted around $10 \%$ of the total main energy source in 2009 worldwide (Cleantech2 2016).

Biochemical and thermal technologies are usually used to convert biomass into energy and fuels in the form of electrical power, heat, or both. Electricity production efficiency from biomass is around $30 \%$, and can reach up to $85 \%$ if heat gain is considered. Biochemical strategies, such as anaerobic digestion, harvest energy in the form of biogas that is transformed to power and heat by means of a gas machine (Cleantech1 2016).

\subsection{The Microbial Process of Anaerobic Digestion}

Anaerobic digestion is a methanogenic decomposer of biomass. It is a reactor, which can be blended or non-blended and warmed or non-warmed. The methodology utilizes a blend of organisms to complete the decomposition. There is no need for feedstock sterilization or contamination concerns. The methane separates and then moves in pipes to a storage tank for later use. Present means of methane production result in a $50-97 \%$ conversion of substrate to methane depending on the feedstock. Carbohydrates substrate yield 50\% methane and $50 \%$ carbon dioxide $\left(\mathrm{CO}_{2}\right)$, while lipids yield higher proportion of methane [Table 1] (Wilkie 2008).

\subsection{Digestion Tanks}

Anaerobic tanks are made of shielded concrete or carbon steel. Air is not necessary, and mixing provides bacteria an avenue for interaction with waste, provides a constant temperature, and prevents solid buildup. The container is equipped with warming and blending tools, a floating top for gas collection, or a detached gas vessel. In the USA and Germany, egg-formed tanks are frequently used as they provide for full blending of the

Table 1. Amount of methane produced from different types of biomass (Wilkie 2008).

\begin{tabular}{lc}
\hline Biomass & $\begin{array}{c}\text { Yield (liter/g of } \\
\text { Volatile Solids) }\end{array}$ \\
\hline Carbohydrate & 0.350 \\
Protein & 0.570 \\
Fat & 0.950 \\
\hline
\end{tabular}


waste due to their declining impact. The tank should be totally blended to let raw influent waste have contact with actively processing waste, thereby speeding up the process, ensuring an even temperature in the tank, and preventing buildup of stones in the tank and the formation of pockets of non-degraded sludge (Esru 2016). There are two commonly used blending systems-mechanical and gas. Gas recirculation systems are used in most modern plants where gas is redirected through the waste. A mechanical system is cheaper to install but more costlier to maintain. A third blending method, draft-tube, is energy effective and recommended for egg-formed tanks (Scottish Envirotech 1995).

\subsection{Energy Recovery}

Biogas is $60-70 \%$ methane, $30-40 \% \mathrm{CO}_{2}$, and traces of different gases such as nitrogen, hydrogen, hydrogen sulphide and water vapor. The caloric value of $70 \%$ methane content biogas is around $21-23.5 \mathrm{MJ} / \mathrm{m}^{3}$, meaning that one cubic meter of biogas matches 0.5-0.6 liters of diesel, or around six $\mathrm{kWh}$ [Table 2] (Rohstoffe 2009). To lend perspective, two kWh is sufficient to run a $100 \mathrm{~W}$ light bulb for 20 hours (Electrigaz 2016). The produced gas may be turned to energy or run the digestion process, saving electricity. The surplus biogas may be utilized in a variety of means, including for combined heat and power generation (CHP), gas distribution, sludge dehydration, and fueling waste incinerators (Frost et al. 1990). Some studies estimate that $150-200 \mathrm{~m}^{3}$ of biogas might be produced from one ton of food waste depending on tank, treatment circumstances, and wastes (Cleantech2 2016).

Electricity generation from biogas is infrequent in developing nations. On the contrary, power generation is the chief target of biogas production in Germany and other industrialized nations. Theoretically, in a fuel cell, biogas may be turned into electricity. However, expensive fuel cells and precise amounts of pure gas are required for this operation. In most cases, biogas fuels a combustion engine, which turns it to mechanical energy that powers an electric generator for electricity production. Gas turbines are used as biogas engines in the USA. They are very costly, small, and their outputs range from 30-75 kW. External combustion engines accept different fuel qualities, but they are rather costly and minimally effective (Giz 2013).
Table 2. Typical details of biogas (Hanjie 2010).

\begin{tabular}{ll}
\hline Composition & $\begin{array}{l}55-70 \% \\
30-45 \% \\
\text { dioxide, traces of } \\
\text { other gases }\end{array}$ \\
\hline Energy content & $\begin{array}{l}6.0-6.5 \mathrm{kWm}-3 \\
\text { Fuel equivalent }\end{array}$ \\
$\begin{array}{l}0.6-0.65 \mathrm{~L} \mathrm{oil} / \mathrm{m}^{3} \\
\text { biogas } \\
6-12 \% \text { biogas in air }\end{array}$ \\
$\begin{array}{l}\text { Explosion limits } \\
\text { Ignition }\end{array}$ & $650-750^{\circ} \mathrm{C}$ \\
temperature & \\
Critical pressure & $75-89 \mathrm{bar}$ \\
Critical & $-82.5^{\circ} \mathrm{C}$ \\
temperature & \\
Normal density & $1.2 \mathrm{~kg} / \mathrm{m}^{3}$ \\
Odor & $\mathrm{Sulphur}$ \\
\end{tabular}

\section{Practical Work}

The aim of the practical work is to estimate the potential of the biomass energy product in the University of Dammam Housing Compound in Petromin District, Eastern Province, Saudi Arabia. The objectives of the study follow:

1. To estimate the amount of biomass produced in the housing compound,

2. To estimate the amount of energy delivered utilizing a hypothetical computation technique generated from past works,

3. To estimate the amount of energy produced using the Biomass Calculation Template as part of the Evaluation of Biomass Resources for Municipalities (EBIMUN) study created by the Waterford County Council (WCC).

\subsection{The Study Area}

The University of Dammam Housing Compound in Petromin District, Dammam City, is located on the main road to the University of Dammam alongside King Saud and King Faisal Roads (Fig. 1). The compound is allocated to the staff of the university, and has both Saudi and expatriate residents. The population is about 820 persons and, when maintenance workers, staff, drivers, and administrative staff are included, the population is 1,200 persons. 


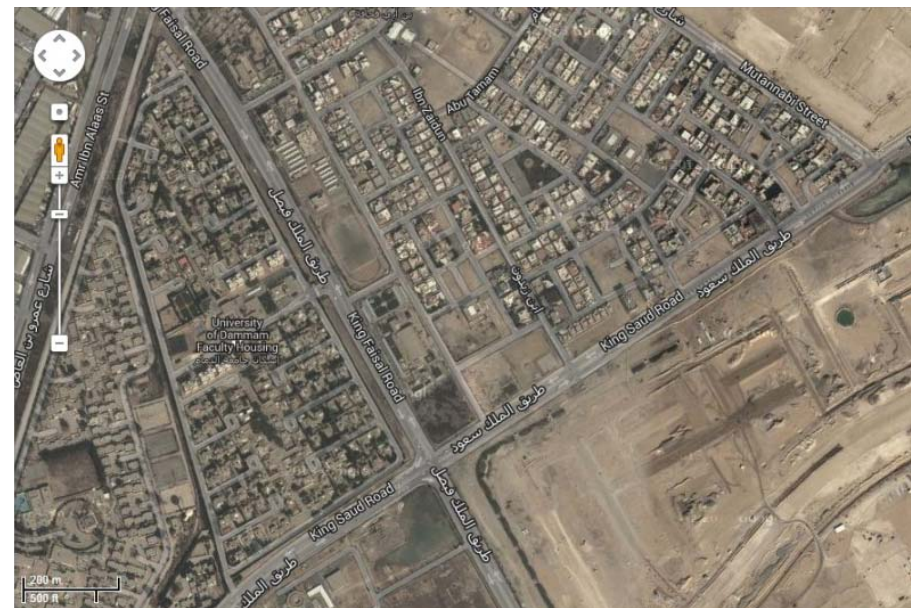

Figure 1. University of Dammam Residential Compound in Petromin.

Table 3. Hypothetical calculation steps.

\begin{tabular}{|c|c|c|c|}
\hline Population size: & 1200 persons & $\begin{array}{l}\text { The per capita MSW in } \\
\text { Saudi Arabia: }\end{array}$ & $\begin{array}{l}1.5-1.8 \mathrm{~kg} / \text { day, and } \\
40 \% \text { of it is biomass } \\
\text { (Zafer } 2015)\end{array}$ \\
\hline $\begin{array}{l}\text { The area can } \\
\text { provide: }\end{array}$ & $\begin{array}{l}1.65 * 1200=1,980 \mathrm{~kg} / \text { day } \\
\text { of MSW containing } 792 \\
\mathrm{~kg} / \text { day of biomass }\end{array}$ & $\begin{array}{l}\text { Each ton of food waste } \\
\text { produces: }\end{array}$ & $\begin{array}{l}150-200 \mathrm{~m}^{3} \text { of biogas } \\
(\mathrm{GP}, 2013)\end{array}$ \\
\hline Potential of biogas: & $\begin{array}{l}0.792 * 175=138.6 \mathrm{~m}^{3} \text { daily, } \\
\left(50,589 \mathrm{~m}^{3} \text { yearly }\right)\end{array}$ & $\begin{array}{l}\text { The average calorific } \\
\text { value of biogas: }\end{array}$ & $\begin{array}{l}\text { 21-23.5 MJ/m³ } \\
\text { (Rohstoffe, 2009) }\end{array}$ \\
\hline $1 \mathrm{~m}^{3}$ of biogas: & $\begin{array}{l}\text { Corresponds to } 0.5-0.6 \text { liter } \\
\text { of diesel fuel, or about } 6 \\
\text { kWh (Rohstoffe, 2009) }\end{array}$ & & \\
\hline $\begin{array}{l}\text { Potential of biomass } \\
\text { energy: }\end{array}$ & $\begin{array}{l}138.6 * 0.55=76 \text { liter of } \\
\text { diesel fuel daily }\end{array}$ & Equivalent to: & $\begin{array}{l}76 * 6=456 \mathrm{kWh} / \text { day, } \\
(166,440 \mathrm{kWh} / \text { year })\end{array}$ \\
\hline
\end{tabular}

\subsection{Potential of Biomass Energy}

This study calculated the energy potential of biowaste in the study area by two different methods. The first method depended on the hypothetical figures regarding generation from biomass, and the second method was based on an Excel sheet (Microsoft, Corp., Redmond, Washington, USA) titled Biomass Calculation Template (EBIMUN) made by the Waterford County Council (WCC) (2013).

\section{Results}

\subsection{Hypothetical Calculations}

Household biomass includes all domestic organic waste such as food, paper, tree leaves, etc. The potential energy production derived from biowaste in the study area was calculated through the following steps (Table 3).

\subsection{Biomass Calculation Template of the Evaluation of Biomass Resources for Municipalities (EBIMUN) Study}

The aim of the EBIMUN project was to increase the capability of the authorities in estimating the local organic waste potential and implement the most effective energy production method (Universidad de Leon 2016). The calculation template is used to calculate the potential of biomass energy of different waste materials from households, industry, sewage etc. From Fig. 2, the total potential of biogas production of the study area is around $43,200 \mathrm{~m}^{3}$ /year, and the methane mass is $18,000 /$ year, the energy production is $900,000 \mathrm{MJ} /$ year, and energy production is $250 \mathrm{MWh} /$ year. Comparing the potential of biogas production from both methods (Table 4 and Fig. 3), the potentials 


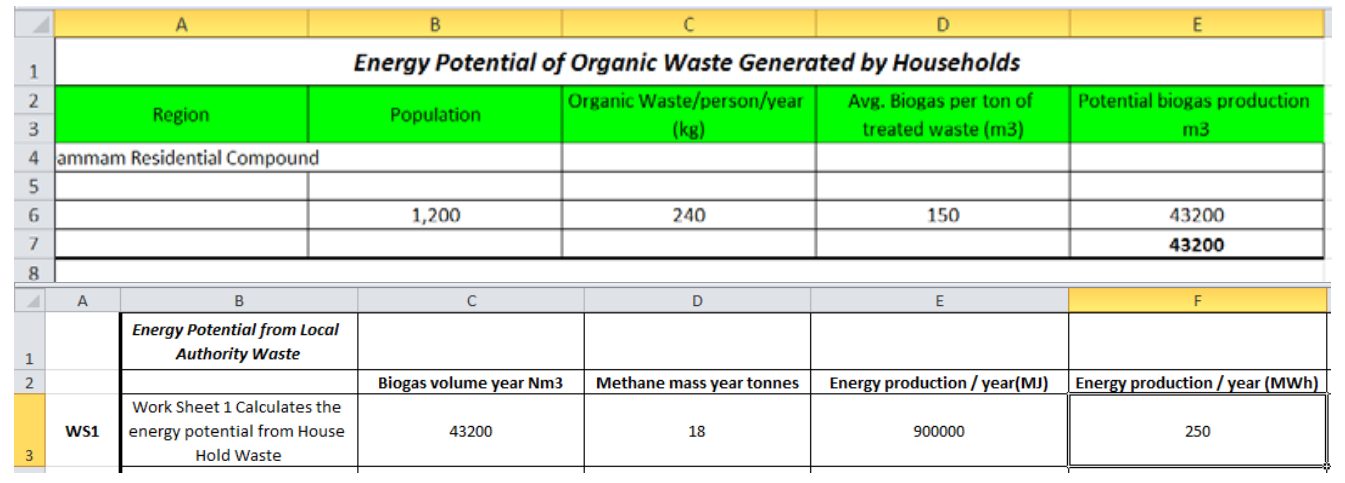

Figure 2: Energy potential of the waste by the EBIMUN template.

Table 4. Biogas and energy potentials in the study area.

\begin{tabular}{lll}
\hline & Theoretical calculations & EBIMUN Template \\
\hline Biogas production potential & $50589 \mathrm{~m}^{3} /$ year & $43200 \mathrm{~m}^{3} /$ year \\
Biomass energy potential & $166440 \mathrm{kWh} /$ year & $143138 \mathrm{kWh} /$ year \\
\hline
\end{tabular}

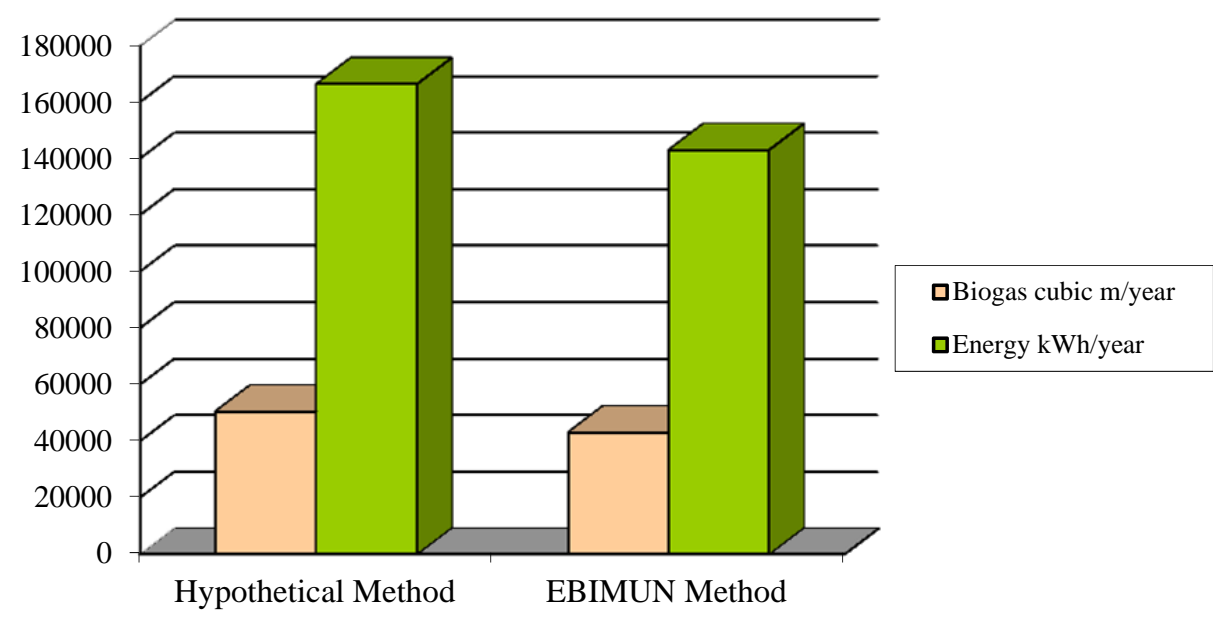

Figure 3. Biogas and energy production potentials in the study area.

estimated by EBIMUN is around 7,000 $\mathrm{m}^{3} /$ year less than the theoretical calculation. The figures suggest that biomass-produced gas is worthy of consideration as a renewable energy source for the study area.

\subsection{The Proposed Plan}

An anaerobic digester is proposed to be placed in the residential compound in order to divert the biomass waste from the municipal waste stream and to produce renewable energy "biogas" that can be used as a local source and distributed to the housing units. In order to increase the outcomes of the operation, it is planned to include the waste produced from the whole neighborhood. The system is proposed as follows: o Establishing a garbage collection system supervised by a board from the compound residents. It includes small trucks, recycling bins, and a collection and classification space.

o Building an anaerobic digester with all required facilities and connections. It should be heated in order to maximize the production rate.

o Extending a network of biogas to supply the residential units.

A study based upon an analysis of the actual monthly electricity consumption for 115 dwellings in Dhahran for the year 2012 (included 62 apartments, 28 villas, and 25 traditional houses), showed that the annual average electricity consumption was 176.5 
$\mathrm{kWh} / \mathrm{m}^{2}$, which was a higher value than international energy-efficiency benchmark (Alrashed and Asif 2014). Saudi Arabia's population has grown rapidly in recent decades, and electricity consumption $(\mathrm{kW})$ per capita was 7,527 kWh in 2013. Considering this figure, the electricity produced from biomass in the study area can fulfill the full needs of around 22 of the 1200 persons in the study area, which is almost $1.8 \%$ of the population.

The energy outcome is obviously very limited due to the limited size of the residential compound, and the high consumption rate of electricity in KSA in general (Alrashid and Asif 2014). As such, recycling biomass for energy conversion should be extended to include the surrounding sites adjacent to the housing compound in order to increase the efficiency of the operation. Therefore, the study proposes that household biowaste should be collected from larger areas, the overall context of $\mathrm{Al}$ Raka District, Petromin District, and Alsafa District, in order to get more biowaste and therefore more energy produced. The majority of electricity consumption in Saudi Arabia is for air conditioning loads; the intent of the proposal, therefore, is mainly to reduce energy needed from the public electricity network.

Biomass collection systems should be placed throughout the district to collect biowaste from houses, shops, markets, restaurants, etc. Local recycling stations will be placed on streets at reasonable intervals with sign boards and usage instructions. This initiative would also benefit from information media (Fig. 4). The collection devices will all be collected and directed to the anaerobic digester, which will be located in the vacant area southeast of the site, where the biomass will be processed for biogas production. A portion of the gas produced will be recirculated within a network of pipes back to houses for cooking use as a replacement to electric stoves. The other portion of produced gas is to be directed into an engine cell to get converted into electricity. This process is always accompanied by heat production, so the heat produced will be used to warm the reactor to the needed temperature in a thermophilic mode to get the maximum production rate of biogas.

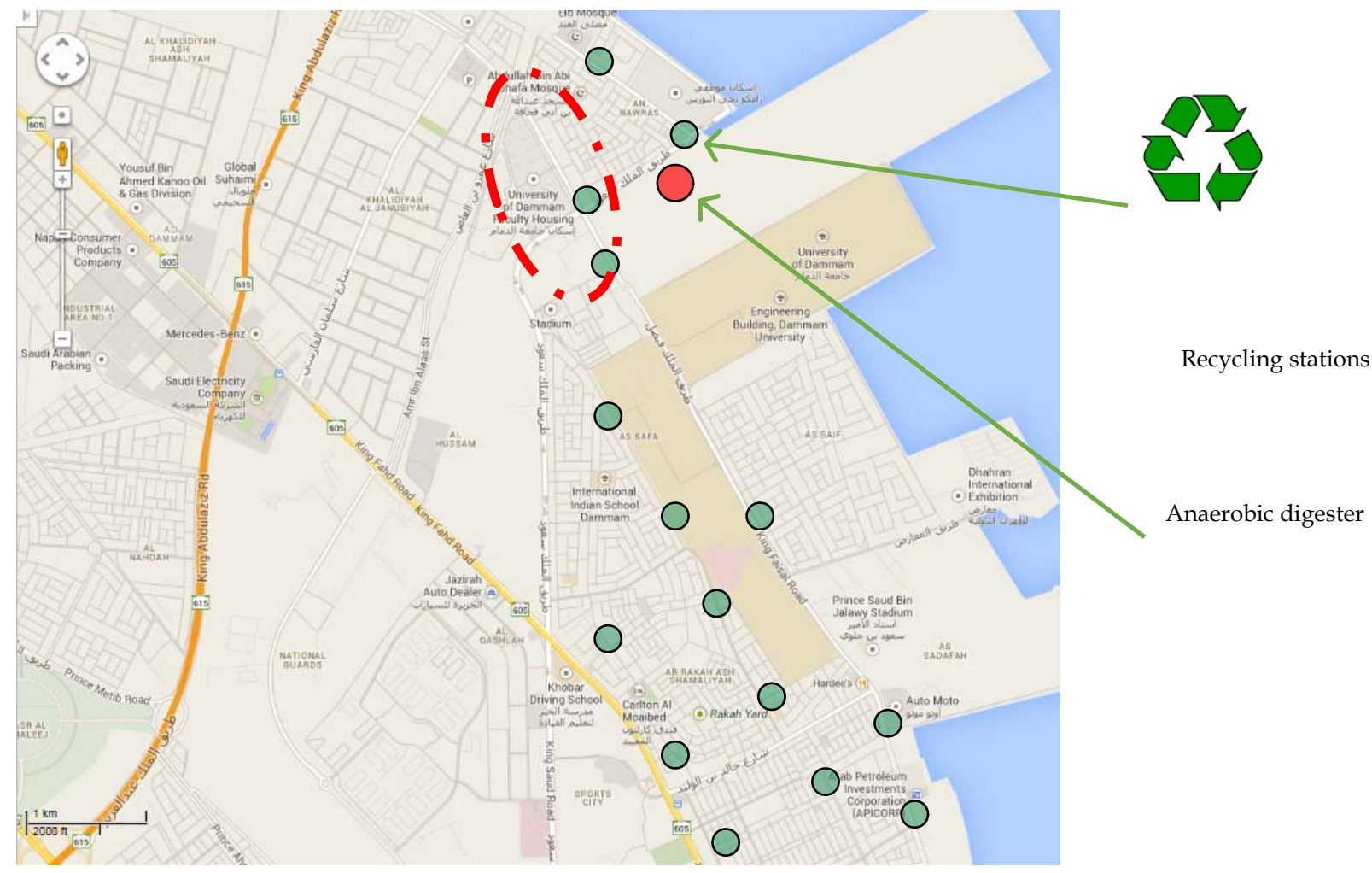

Figure 4. Proposed plan at the university housing compound. 


\section{Conclusion}

The current study sought to contrast the potential energy created by the two distinct strategies. The hypothetical technique delivered around $51,000 \mathrm{~m}^{3}$ of biogas, which surpassed about $18 \%$ of the biogas delivered by the EBIMUN strategy, which was evaluated at $43,000 \mathrm{~m}^{3}$.

The contrast between the two strategies may be clarified when the accompanying elements that firmly influenced the beneficial possibilities of energy from biomass are considered:

- The assorted qualities in the sort and synthesis of organic waste, whether provincial squanders, household, agricultural, sludge, energy crops, catering waste, industrial waste, or harvested biomass- noticeably affected the outcomes. These differences can be seen from city to city, and from nation to nation and prompts the varieties of carbon substance in the waste, and along these lines the varieties in the measure of energy delivered.

- The variety of environmental conditions under which the organic waste was produced and delivered affected the resultant energy. The variation in the quality of fertilizers and animal feed utilized as well as the climate conditions such as the amount of rain, moisture content and temperature ranges, and other atmospheric conditions influenced the synthesis of the waste and its humidity content.

- The assortment of the accessible technologies in the form of digestion tanks from the European Union where EBIMUN is embraced and in other nations where the hypothetical estimation strategy was involved logically, affect energy creation outcomes.

- Including just the waste created by the University of Dammam housing compound would not result in enough biomass. Along these lines, energy generation would be significantly more advantageous if the three locales around the compound-Petromin, Al Raka, and Alsafa - were to be included.
Saudi Arabia has a wide range of assets in the area of biomass waste. It has the potential to generate renewable energy and decrease reliance on fossil fuels. It is also among the top ten waste-generating nations in the world. However, these opportunities are not being utilized yet. In the small community presented in the study, about $2 \%$ of the energy required for family utilization can be obtained by domestic biomass anaerobic digestion. If wastewater treatment, including anaerobic digestion of both domestic and industrial sewage streams, were to be added, more biogas could be produced and a greater reduction in dependency on electricity networks could be accomplished. The proposed framework might play an imperative part in energy saving and generation.

\section{Recommendations}

Efforts should be directed to increase the amount of household organic waste that can be collected from the residents of the housing complex.

A team of volunteers from the residents of the housing complex should be recruited in order to oversee the implementation and development of this proposal

Collection and classification bags for organic waste should be supplied to every residential unit in the compound, and the time and location of organic waste collection should be conveyed to the population

Wedding halls, specialized kitchens in the neighborhoods, and restaurants should be contacted and coordinated with in order to incorporate the remnants of their events into the anaerobic digester.

The population of the housing compound and of Saudi Arabia should be made aware of the importance organic waste and renewable energy use.

A simulation model for the area should be developed that depicts the amount of energy consumed before and after implementation of the proposal and reflects the benefits from the proposed energy saving. The model should detail the economic impact of the proposal on the local population.

A board should be assembled to approach the bodies concerned with the treatment of municipal waste in order to coordinate the 
possibility of establishing an organic waste sewage plant linked to the anaerobic digester to increase production efficiency and rates of recycling.

It would be more advantageous to include the three surrounding districts-Petromin, $\mathrm{Al}$ Raka, and Alsafa - in the framework in order to reap enough usable waste and, consequently, energy generation.

Nearby neighborhoods, districts, towns, and cities should encourage their inhabitants to embrace recycling mechanisms and elevate biomass to increase energy conversion.

Biomass energy should be utilized as a vital source of renewable energy that can be applied to save the earth from pollution and add to the economy by saving conventional energy production costs.

Biomass conversion innovation should be embraced in all nations. More investigation should be urged to develop more potential sources for energy protection and lessen the amount of solid waste being disposed of after just a single use.

\section{Acknowledgment}

This Project (no. 2012168) was funded by the Deanship of Scientific Research at the University of Dammam.

\section{References}

Alrashed F, and Asif M (2014), Trends in residential energy consumption in Saudi Arabia with particular reference to the Eastern Province. Journal of Sustainable Development Energy, Water and Environmental Systems 2(4): 376-387.

Appels L, Baeyens J, Degrève J and Dewil R (2008), Principles and potential of the anaerobic digestion of waste-activated sludge. Energy and Combustion Science 34:755-781.

Bioenergy1 (2016), Biomass feedstock in the Middle East and North Africa. From bioenergyconsult.wordpress.com/2011/09 /30/biomass-feedstock-in-middle-eastand-north-africa-mena. Accessed Apr 2016.

Bioenergy2 (2016), Municipal wastes in Saudi Arabia. From bioenergyconsult.com / municipal-wastes-in-Saudi-Arabia. Accessed April 2016.

Cleantech1 (2016), Introduction to biomass energy. From www.cleantechloops.com / an-introduction-to-biomass-energy. Accessed April 2016.

Cleantech2 (2016), A glance at biomass energy. From www.cleantechloops.com/a-glanceat-biomass-energy. Accessed Apr 2016.

Electrigaz (2016), Biogas FAQ. From www.electrigaz.com/faq_en.htm. Accessed Apr 2016.

Esru (2016), Energy from waste. From www.esru.strath.ac.uk/EandE/Web_sites/ 97-8/energy_from_waste/ page3.htm. Accessed Jan 2016.

Frost R, Powlesland C, Hall JE, Nixon SC, and Young C.P (1990), Review of sludge treatment and disposal techniques. WRC Report PRD 2306-M/1.

Giz (2013), Small scale electricity generation from biomass: Part 2. From www.giz.de/Themen/de/dokumente/gtz 2010-en-small-scale-electricity-generationfrom-biomass-part-2.pdf. Accessed May 2013.

Google Maps (2016), Petromin area, Dammam City, KSA. From www.google.com/maps/search/petromin +dammm+ksa/@26.4067682,50.1638835,16z Accessed Jun 2016.

Green Power (GP) (2013), Green power. From www.Greenpower.cn. Accessed Jul 2013.

Hanjie Z (2010), Sludge treatment to increase biogas production, TRITA-LWR Degree Project 10-20, KTH Land and Water Resource Engineering, Sweden.

Jun H (2013), Saudi Arabia's domestic energy situation and policy: Focusing on its power sector. Kyoto Bulletin of Islamic Area Studies 107-135.

Myriad Power (2016), An anaerobic digester image. From myriadpower.com / anaerobic.html. Accessed Sep 2016.

Rohstoffe FN, (2009), Biogas basisdaten Deutschland - Stand. 7p. Very short but comprehensive overview of the biogas situation in Germany. From www.fnrserver.de/ftp/pdf/literatur / pdf_185basisdaten _ biogas _ 2009.pdf. Accessed Apr 2016.

Scottish Envirotech (1995), Scottish Envirotec. 3(3): 24-25.

U.S. Department of Energy (DOE) (2000), Biofuels for sustainable transportation, The National Renewable Energy Laboratory, A DOE National Laboratory. DOE/GO102000-0812. From portal.ncdenr.org / c / document_library/get_file?uuid $=41 \mathrm{c} 5 \mathrm{f} 270$ 
- 58d7 - 4930-93d3 -172e1b0d2cd \& groupId=38322. Accessed Mar 2016.

Universidad de Leon (2016), Evaluation of biomass resources for municipalities (EBIMUN-BIO-EN-AREA). From www.unileon.es / investigadores/ proyectos-internacionales-de-IDi/ebium. Accessed Jun 2016.

Waterford County Council (WCC) (2013), EBIMUN: Evaluation of biomass resources for municipalities. From www.bioenarea.eu / index.php?q =node $/ 217$. Accessed Mar 2014.
Wilkie AC (2008), Biomethane from biomass, biowaste, and biofuels. Bioenergy, ASM Press, Washington.

Zafer S (2015), Solid waste management in Saudi Arabia. From www.ecomena.org / solid-waste-manage-ment-in-SaudiArabia. Accessed Jun 2016. 